logos_i_ethos_2015_1_(38), s. 167-181

DOI: http://dx.doi.org/10.15633/lie.1051

Wojciech Surówka OP

Instytut Nauk Religijnych św. Tomasza z Akwinu w Kijowie

Podwójny renesans

\title{
Teresa Obolevitch, Filozofia rosyjskiego renesansu patrystycznego, Copernicus Center Press, Kraków 2014, ss. 351
}

To tej pory nie było jeszcze w polskiej literaturze teologicznej książki, która poruszałaby całościowo problematykę „syntezy neopatrystycznej" w prawosławnej myśli XX wieku. Lukę tę wypełnia ostatnia publikacja $\mathrm{dr}$ hab. Tere-
Wojciech Surówka OP - dominikanin, teo$\log$ i publicysta. Od 2011 roku pełni funkcję dyrektora Instytutu Nauk Religijnych św. Tomasza z Akwinu w Kijowie. Publikował w „Przeglądzie Tomistycznym”, „Studia Oecumenica”, „Więzi”, „Przeglądzie Politycznym”, „W Drodze”.

sy Obolevitch ${ }^{1}$. Przyznam szczerze, że ze zniecierpliwieniem czekałem na tę książkę i przeczytałem ją jednym tchem. Autorka pisze o postaciach znanych polskiemu czytelnikowi, których poglądy do tej pory były jednak stosunkowo słabo opracowane. Już sam tytuł książki wskazuje, że będziemy mieli do czynienia z opracowaniem z pogranicza filozofii i teologii. Zapewne wybór takiej właśnie perspektywy czyni książkę niezwykle interesującą. Oczywiście nie jest możliwe w ramach krótkiej recenzji odnieść się do wszystkich kwestii poruszonych w książce.

1 T. Obolevitch, Filozofia rosyjskiego renesansu patrystycznego, Kraków 2014. W cytowanych przez Autorkę polskojęzycznych publikacjach nie znajdziemy ani jednej, która próbowałaby całościowo ogarnąć problematykę renesansu patrystycznego. Jak do tej pory najbardziej obszernym było opracowanie K. Leśniewskiego, które omawiało zasadniczo ekumeniczny wymiar teologii G. Fłorowskiego. Zob. K. Leśniewski, Ekumenizm w czasie. Prawosławna wizja jedności w ujęciu Georges'a Florovsky'ego, Lublin 1995. 
Autorka znakomicie przedstawia religijną myśl rosyjskich emigrantów na tle historii filozofii rosyjskiej. Powiem nawet więcej, jej rzetelność w relacjonowaniu poglądów omawianych myślicieli można uznać za wzorcową. Nie będę więc pisać o tym, co zostało znakomicie przez Autorkę opracowane, ani o brakach, których Autorka jest świadoma, chciałbym spróbować poszerzyć horyzont omawianych problemów, do czego zresztą zachęca sama Autorka, świadoma nieuniknionych ograniczeń własnej pracy.

Po przeczytaniu książki Teresy Obolevitch odniosłem wrażenie, że mamy do czynienia z podwójnym renesansem w prawosławnej myśli $\mathrm{XX}$ wieku. Z jednej strony mamy do czynienia $\mathrm{z}$ filozoficznym renesansem Srebrnego Wieku, $\mathrm{z}$ drugiej natomiast $\mathrm{z}$ renesansem patrystycznym. Myśl ta przenika całość rozważań, a zostaje przez Autorkę wprost wypowiedziana w ostatnim akapicie:

Koncepcje naszych bohaterów stanowią nie tyle alternatywę, ile istotne uzupełnienie dyskursu filozoficzno-religijnego rozwijanego w myśli rosyjskiej w XX stuleciu. Nie należy ich traktować w sposób ekskluzywny, lecz komplementarny względem tradycji intelektualnej Srebrnego Wieku oraz dorobku filozoficzno-naukowego naszych czasów².

Interesująca wydaje się relacja, jaka zachodzi pomiędzy tymi dwoma wymiarami renesansu w rosyjskiej myśli XX stulecia. Teresa Obolevitch przekonuje o komplementarności tych dwóch tradycji. Myślę, że jeśli taka komplementarność zachodzi, to jest ona efektem spojrzenia na te zagadnienia z naszej perspektywy. Czytając książkę, odniosłem wrażenie, że mimo wszystko renesans patrystyczny był alternatywą dla religijnej filozofii Srebrnego Wieku. Szczególnie ciekawe wydają się dwie kwestie, a mianowicie relacja pomiędzy filozofią i teologią, a co za tym idzie, stosunek wiary i rozumu, jak również kwestia rozumienia samego renesansu patrystycznego. 
Głównymi bohaterami książki są o. Gieorgij Fłorowskij i Włodzimierz Łosski, dwaj rosyjscy emigranci, którzy trafili na Zachód w drugiej dekadzie XX wieku, i to właśnie tam ukształtowało się ich specyficznie prawosławne myślenie. Autorka przedstawia ich poglądy na szerokim tle historii rosyjskiej filozofii, jednak warto zwrócić uwagę na fakt, że nie stroni od pokazania bardzo ważnych odniesień do wielu nurtów filozofii i teologii zachodniej. Badania Teresy Obolevitch po raz kolejny pokazują wzajemne przenikanie się wschodniego i zachodniego stylu uprawiania filozofii wśród rosyjskiej emigracji. Bezsporną zaletą omawianego opracowania jest pokazanie unikalności rosyjskich myślicieli, polegającej na śmiałym połączeniu tradycji zachodniej filozofii ze wschodnim doświadczeniem religijnym. Kluczem do opracowania materiału jest relacja pomiędzy wiarą i rozumem. Jak trafnie zauważa Autorka, zagadnienie to pojawia się już w tekstach staroruskich.

Myśl staroruska charakteryzuje się nie tyle dążeniem do pogodzenia fides i ratio, ile ich dyfuzją, wzajemnym przenikaniem się. Na Rusi filozofia jako odrębna dyscyplina nie istniała, a więc także opozycja filozofia-teologia [...] nie występowała w czystej postaci. [...] Raczej należy stwierdzić, że między fides a ratio w kulturze staroruskiej nie było ani otwartych konfliktów, ani też współpracy owocującej rozwojem dyskursu filozoficzno-teologicznego ${ }^{3}$.

Długi czas myśl rosyjska charakteryzowała się dominacją teologii nad filozofią. Filozofia jako samodzielna dyscyplina pojawiła się wraz z Oświeceniem i od razu nabrała czysto „świeckiego" charakteru. Przykładowo w publikacjach znakomitego historyka idei Andrzeja Walickiego prawie nie znajdziemy odniesień do wymiaru religijnego rosyjskiej filozofii. Dopiero wiek XIX przyniesie próby pogodzenia tych dwóch nurtów myślenia. Będą one podejmowane zarówno ze strony religijnych myślicieli, takich jak Nikołaj Fiodorow, Fiodor Dostojewski czy Włodzimierz Sołowjow, jak również w kręgach akademickiej filozofii. 
Niemal wszyscy przedstawiciele filozofii akademickiej dążyli do syntezy filozofii i teologii. [...] W ten sposób ukształtowała się duchowno-akademicka „szkoła wierzącego rozumu"4.

Wspominam o tych dwóch nurtach, ponieważ będą one w późniejszym okresie przedmiotem krytyki ze strony Fłorowskiego. Twórcy renesansu patrystycznego nie szczędzili słów krytyki pod adresem tego typu prób. „[...] spekulatywne, metafizyczne podejście do prawd wiary chrześcijańskiej, rozpoczęte przez Sołowjowa i kontynuowane przez Bułgakowa, było przedmiotem nieustannej krytyki ze strony Fłorowskiego i Łosskiego" ${ }^{-}$- pisze Teresa Obolevitch i zauważa, że „myśl rosyjską cechuje pewne napięcie między logosem a ratio, objawioną mą-

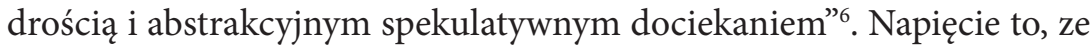
swej natury twórcze, owocujące ciekawymi próbami syntezy filozofii i teologii, dokonało się dzięki „szkolnemu” nurtowi filozofii akademickiej, jak również, a może przede wszystkim dzięki odważnej religijnej filozofii poprzedników Srebrnego Wieku, szczególnie wspomnianych już Fiodorowa, Dostojewskiego i Sołowjowa. Zaproponowany przez tych autorów sposób ujęcia relacji pomiędzy wiarą i rozumem był dla twórców renesansu patrystycznego niewystarczający, a nawet szkodliwy.

Podczas gdy reprezentanci renesansu religijno-filozoficznego podejmowali próby racjonalizacji prawd wiary (takie podejście można określić mianem filozofii w ramach teologii czy filozofii teologicznej), Fłorowski i Łosski zaproponowali alternatywę w postaci renesansu patrystycznego - utożsamienia filozofii i teologii, a nawet filozofii i mistyki ${ }^{7}$. [...] Stanowisko Fłorowskiego na temat relacji między nauką i religią można określić jako pewną odmianę konkordyzmu - wykazania, że konflikt między tymi dziedzinami jest niemożliwy, gdyż wszystkie dane nauki są podporządkowane (albo należy podporządkować) prawdom objawionym. Jest to

Tamże, s. 32-33.

Tamże, s. 61.

Tamże, s. 35.

Tamże, s. 291. 
wymowny przykład tezy Fłorowskiego o prymacie religii we wszystkich dziedzinach życia ${ }^{8}$.

Fłorowski wysuwał „postulat uprawiania teologii na podstawie żywego doświadczenia wiary, czyli «teologii kontemplacyjnej», przy jednoczesnym poszanowaniu twórczego poszukiwania prawdy" . Od samego początku wydaje się, że niezgoda na "renesans filozoficzny” jest stałym elementem uprawianej przez Fłorowskiego teologii.

W latach trzydziestych Fłorowski ostatecznie określił, na czym ma polegać owa synteza, nowa droga rozwoju myśli rosyjskiej. Jak pisał, dotychczas „filozofia zmierzała do teologii, a nie wychodziła z teologii”: motywy platońskie obecne w myśli rosyjskiej miały charakter propedeutyczny, prowadzący do świata patrystyki, podczas gdy dziedzictwo Ojców winno być punktem wyjścia dla wszelakich rozważań teologiczno-filozoficznych ${ }^{10}$.

Trzydzieści lat później pisze w liście do Jurija Iwaska:

Przyjąłem „renesans” na poważnie i właśnie dlatego doszedłem do jego zanegowania i odrzucenia. [...] O renesansie mogę powiedzieć, że [jego przedstawiciele] „nie znaleźli drogi”. Nie widzę, aby ktoś naśladował drogę sofiańską. O ojcu Sergiuszu już prawie zapomniano. Bierdiajewa też mało kto naśladuje. Jest to zrozumiałe - przecież nie ma dokąd iść i drogi też nie ma. [...] Wszystko, co obecnie mówi się o renesansie, nie jest niczym innym jak tylko etiudą na temat: „O miłości do Ojczyzny i dumie narodowej”. [...] Wszystkie złudzenia zostały rozwiane. „Teologii rosyjskiej" nie ma i nie było ${ }^{11}$.

Myślę, że chwilowo możemy zatrzymać się przy tym zdaniu i przypatrzeć się dwóm sposobom ujmowania relacji między wiarą i rozumem

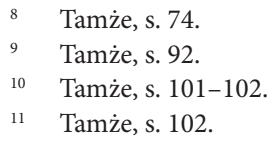


w myśli rosyjskiej. Kiedyś Leszek Kołakowski pisał, że „filozofia nie uwolniła się nigdy od dziedzictwa teologii”"12. Szczególnie jest to widoczne w przypadku filozofii rosyjskiej, która w bardzo dużym stopniu naznaczona jest doświadczeniem religijnym. Sam tytuł książki Teresy Obolevitch Filozofia rosyjskiego renesansu patrystycznego daje nadzieję na zapoznanie się przede wszystkim z zagadnieniami filozoficznymi. $\mathrm{W}$ tekście są one jednak mocno splecione $\mathrm{z}$ tematyką teologiczną, co cieszy teologa, może jednak rozczarować filozofa. W polskojęzycznej literaturze przedmiotu posiadamy znakomite opracowywania filozofii rosyjskiej, które wyszły spod pióra Andrzeja Walickiego, Grzegorza Przebindy, czy w ostatnich latach Sławomira Mazurka ${ }^{13}$. Zasługują one na miano opracowań klasycznych, jednak nawet jeśli poruszają kwestie religijne, jak w przypadku książek Przebindy czy Mazurka, ograniczają się do omówienia zagadnień czysto filozoficznych. Teresa Obolevitch w swych rozważaniach idzie dalej niż wymienieni autorzy. Do omawianej problematyki włącza dwie kwestie specyficznie teologiczne. Mowa o dwóch wielkich dyskusjach w łonie prawosławnej tradycji początku XX stulecia, a mianowicie o kwestii sofiologicznej i sporze wokół imiesławia. Szczególnie ostatnia kwestia wydaje się być płodną filozoficznie $^{14}$. Poszerzenie horyzontu badań nad filozofią rosyjską o te dwa, specyficznie teologiczne zagadnienia jest wielką zasługą opracowania Teresy Obolevitch. Można powiedzieć, że tym samym stara się wypełnić postulat Fłorowksiego. Teologia powinna być punktem wyjścia dla wszelkiego myślenia, również dla myślenia filozoficznego.

Relacja pomiędzy wiarą i rozumem jest zagadnieniem, do którego Fłorowski powracał przez całe życie. Poszerzając horyzont omawianego

12 L. Kołakowski, Kapłan i błazen, [w:] tegoż, Pochwała niekonsekwencji. Pisma rozproszone $z$ lat 1955-1968, t. 1, Londyn 1985, s. 161.

13 A. Walicki, Zarys myśli rosyjskiej. Od Oświecenia do Renesansu religijno-filozoficznego, Kraków 2005; G. Przebinda, Od Czaadajewa do Bierdiajewa: spór o Boga i człowieka w myśli rosyjskiej 1832-1922, Kraków 1998; S. Mazurek, Rosyjski renesans religijno-filozoficzny. Próba syntezy, Warszawa 2008.

14 Szerzej na temat tej kwestii zob. T. Obolevitch, Od onomatodoksji do estetyki, Kraków 2011. 
zagadnienia, chciałbym odwołać się do opracowań dwóch współczesnych rosyjskich badaczy. We wstępie do zbioru kluczowych artykułów Fłorowskiego Igor Ewlampiew stwierdza, że w rosyjskiej myśli są zauważalne dwie tendencje. $\mathrm{Z}$ jednej strony myśl filozoficzna jest prawie całkowicie pochłonięta przez teologię, co prowadzi do stworzenia swego rodzaju „teozofii”, jak miało to miejsce w wypadku filozofii Sołowjowa. $\mathrm{Z}$ drugiej strony istnieje przeciwna tendencja, której przykładem może być twórczość Sergiusza Bułgakowa, który porzucił filozofię, aby poświęcić się teologii. Zdaniem Ewlampiewa przypadek Fłorowskiego, który również rozpoczął swoją karierę jako świecki filozof, aby następnie z pozycji teologii służyć Kościołowi prawosławnemu, wydaje się o wiele bardziej interesujący ${ }^{15}$. Ewlampiew zwraca uwagę na jeszcze jeden bardzo ciekawy aspekt. Fłorowski zdecydowanie występował przeciw wszelkim próbom odnowienia chrześcijańskiej tradycji za pomocą współczesnej filozofii, nie jest mu jednak obca troska o dialog ze współczesnością. Obiera on jednak zupełnie inną drogę niż jego koledzy, twórcy „renesansu filozoficznego”. Autorzy „renesansu filozoficznego" nie byli w stanie pogodzić się z „,kanonicznym prawosławnym światopoglądem. [...] Nie mogli wyobrazić sobie jego rozwoju w zastanych dogmatycznych ramach"16. Celnie taką postawę scharakteryzował, nota bene utożsamiając się z nią, Mazurek.

Rosyjski renesans był wreszcie filozofią religijną, a ściśle filozofią chrześcijańską [...]. Rosyjski renesans nie był jednak filozofią konfesyjną, uzależnioną od określonego wyznania, kościoła czy ortodoksji. Wręcz przeciwnie - nastawienie eschatologiczne, mniej lub bardziej jawny profetyzm, zainteresowanie rozmaitymi nurtami mistyki i religijny indywidualizm w naturalny sposób łączy się tu z bezpardonową krytyką historycznego chrześcijaństwa. Rosyjscy myśliciele niemal jednogłośnie stwierdzali, że nie wypełniło ono swojej misji i w konsekwencji przyczyniło się do zaistnienia głębokiego konfliktu między religią i kulturą. [...] W dzisiejszych cza-

15 И. И. Евлампиев, Богословие против философии: творческое служение Георгия Флоровского, [w:] Г. Флоровский, Христианство и иивилизация, Санкт-Петербург 2005, s. 5.

16 Tamże, s. 8. 
sach, a są to czasy wyjątkowej ideologizacji i upolitycznienia religii, trudno przecenić wagę tych refleksji. Alternatywą dla chrześcijaństwa ideologicznego, co najmniej ocierającego się o fundamentalizm i uwięzionego w kręgu zawsze tych samych obyczajowych obsesji, może być chrześcijaństwo filozoficzne, wolne od uprzedzeń wobec nowoczesności, a jednocześnie odważnie, w żywym języku refleksji, a nie martwym języku doktryny, mierzące się ze wszystkimi przeklętymi problemami, jakie nowoczesność ta ze sobą niesie ${ }^{17}$.

Fłorowski starał się wypracować zasady twórczego podejścia do tradycji prawosławnej, bez uciekania się do osiągnięć współczesnej filozofii. Polem jego badań był dogmat. Jak pisze Ewlampiew:

Starał się pokazać możliwość współczesnej interpretacji dogmatów i współczesnego odczytania dziedzictwa Ojców bez naruszania dogmatycznej dyscypliny prawosławnego światopoglądu ${ }^{18}$.

Myślę, że w przyszłości warto byłoby pogłębić właśnie ten wątek, a mianowicie problematykę wzajemnej relacji filozofii i dogmatu. Bardzo ciekawe opracowanie na ten temat przedstawił jakiś czas temu Lew Szaposznikow $^{19}$. Jego monografia, choć nie wolna od pewnych uproszczeń, jest próbą przyjrzenia się prawosławnej tradycji w kontekście współczesnej filozofii. Autor przedstawia złożone relacje pomiędzy dogmatyką, eklezjologią i filozofią, umieszczając je w kontekście trzech nurtów myśli rosyjskiej: konserwatyzmu, nowatorstwa i modernizmu. Za skrajne uważa konserwatyzm i modernizm. Żaden z nich tak naprawdę nie przedstawia prawdziwej tradycji prawosławnej. Również w tym przypadku, podobnie jak u Ewlampiewa, kluczowym zagadnieniem jest stosunek teologii do filozofii. Konserwatyzm odrzuca filozofię, modernizm natomiast przekształca teologię w filozofię religii. Najbardziej twórczy

17 S. Mazurek, Rosyjski renesans..., dz. cyt., s. 10-11.

18 И. И. Евлампиев, Богословие против философии..., dz. суt., s. 8.

19 Л. Е. Шапошников, Консерватизм, модернизм и новаторство в русской православной мыстл ХІХ-ХХІ веков, Санкт-Петербург 2006. 
ruch nazywa on nowatorstwem. Zdaniem autora charakteryzuje się ono twórczym podejściem do filozofii w ramach teologii. Nazywa tę drogę „ukościelnieniem filozofii” co moglibyśmy chyba przetłumaczyć jako „ochrzczenie filozofii”20. Najbardziej ciekawa wydaje się analiza dogmatyki prawosławnej w kontekście rozwoju dogmatu. Zdaniem autora:

[...] panującą tendencją rosyjskiej teologicznej myśli na emigracji było nowatorstwo. [...] Prawosławie jest nie do pomyślenia poza historią i w związku z tym, jest ono „rosnącą i rozwijającą się tradycją” - i właśnie dlatego rosyjska teologia powinna być twórcza ${ }^{21}$.

Poważnym brakiem monografii Szaposznikowa jest niejasność dotycząca relacji pomiędzy konserwatyzmem, nowatorstwem i modernizmem. Autorowi nie udaje się do końca uchwycić specyfiki relacji pomiędzy filozofią i teologią. Omawia poglądy wielu bardzo ciekawych autorów, jednak gdy następuje moment dokonania syntezy zebranego materiału, jakby zaczyna brakować jasności w argumentacji. Zasadniczo odnosi się wrażenie, że nowatorstwo jest tym twórczym nurtem teologii, który zyskał aprobatę hierarchii kościelnej. Wyznaczenie kryteriów twórczego rozwoju teologii, jako najważniejszego problemu postawionego w książce, pozostaje niedopracowane.

Jestem przekonany, że jednym z kluczowych zagadnień w przyszłych badaniach nad renesansem patrystycznym będzie pokazanie łączności pomiędzy myślą twórców renesansu patrystycznego a dokonaniami teologów wcześniejszego pokolenia. Zagadnienie relacji wiary i rozumu było poruszane przez wielu teologów akademickich końca XIX początku XX stulecia. Myślę, że krytyczna opinia Fłorowskiego zaciążyła na nikłej recepcji ich myśli w XX wieku. W 2013 roku w Doniecku została wydana ogromna monografia poświęcona tej tematyce ${ }^{22}$. Ta

20 Por. tamże, s. 7.

${ }_{21}$ Tamże, s. 89.

22 І. П. Печеранский, Співвідночення віри і розуму в православно-академічному теїзмі XIX - початку XX століття, Донецьк 2013. 
500-stornicowa książka (przy normalnym składzie stron byłoby dwa razy więcej) omawia prawie wszystkich znaczących prawosławnych teologów końca XIX i początku XX wieku. Jedną z tragedii rosyjskiej teologii było przerwanie tej ciągłości. Czytając książkę Teresy Obolevitch odnoszę wrażenie, że nadmiernie podkreślona została unikalna rola renesansu patrystycznego. Krytyczne stwierdzenie Fłorowskiego: „Teologii rosyjskiej nie ma i nie było" jest krzywdzące względem ogromnie bogatej twórczości teologicznej jego poprzedników. Takie nazwiska, jak Pamfił Jurkiewicz, Paweł Swietłow, Michaił Taraeew, Wiktor Niesmełow, Fiodor Buharew, Nikolai Golubinski zostają w dużej mierze nieodkryte w polskojęzycznej literaturze przedmiotu. Jestem przekonany, że ich próba opisania relacji pomiędzy wiarą i rozumem nie jest jedynie „pustą dyskusją", jak twierdzi Aleksei Nesteruk ${ }^{23}$, kontynuator myśli Fłorowskiego, często wspominany w książce Teresy Obolevitch. Zdaniem Igora Pecheranskiego problem współczesnej prawosławnej teologii polega na utożsamieniu prawosławnej myśli z jednym tylko jej nurtem, $\mathrm{z}$ „neopatrystyką" lub „neopalamizmem”. Obecnie mówi się już o „postpatrystycznej syntezie". Pecheranski postuluje uzupełnienie syntezy postpatrystycznej o syntezę neoakademicką $a_{\text {24 }}^{24}$.

Należy poruszyć jeszcze kwestię samego renesansu patrystycznego. Fłorowski i Łosski zasłynęli przede wszystkim jako inicjatorzy tzw. syntezy neopatrystycznej, czyli odrodzenia myśli ojców Kościoła w czasach współczesnych. Właśnie wokół tego programu wyznaczającego ich działalność Autorka koncentruje swe „rozważania mające na celu rekonstrukcję i analizę ich dorobku filozoficzno-religijnego" ${ }^{25}$. Fłorowski postulował odejście od latynizmu i powrót w stronę dziedzictwa patrystycznego.

Należy przezwyciężyć zachodnie wpływy w teologii rosyjskiej. To dotyczy przede wszystkim „stylu zachodniego”. [...] Teologia prawosławna może przywrócić

23 Por. А. Нестерук, Логос и Космос: Богословие, наука и православное предание, Москва 2006, s. 57; I. П. Печеранский, Співвідношення віри і розуму..., dz. суt., s. 8.

24 І. П. Печеранский, Співвідношення віри і розуму..., dz. суt., s. 464.

25 T. Obolevitch, Filozofia rosyjskiego..., dz. cyt., s. 11. 
niezależność od wpływów zachodnich tylko poprzez duchowy powrót do patrystycznych źródeł i podstaw ${ }^{26}$.

Fłorowski uważał, że przezwyciężenie wpływów Zachodu nie oznacza ani całkowitego zerwania z kulturą Zachodu, ani wrogości wobec tej ostatniej. W Drogach teologii rosyjskiej zaproponował cztery warunki odnowy „stylu patrystycznego" stanowiącego istotę odrodzenia teologii w ogóle: (1) soborowość, (2) powrót do dziedzictwa Ojców, (3) hellenizm chrześcijański i (4) historyzm ${ }^{27}$. Dla Fłorowskiego historyczność jako miejsce objawienia bytu zastąpiła tradycyjną dla prawosławia „mistyczność" 28 . Historia była dla niego nie zwykłą pulsacją życia lub „pędem życiowym”, lecz wysiłkiem ascetycznym. To indywidualna twórczość, a nie bieg historii ma charakter absolutny. Zwrot ku przeszłości oznacza kontynuację historii, która nie istnieje „bez retrospektywy, czyli perspektywy"29.

Chodzi nie o jakąś „restaurację” i nie o zwykłe powtórzenie czy zwrot do tyłu. W każdym razie „ku Ojcom” trzeba iść do przodu, a nie do tyłu ${ }^{30}$.

Jestem przekonany, że program Fłorowskiego wymaga trzech uzupełnień. Słusznie zostało zauważone przez Teresę Obolevitch, że renesans patrystyczny jest zjawiskiem paralelnym do tego, które pojawiło się w środowisku katolickich teologów. Podkreślenie tego faktu ma ogromne znaczenie dla umieszczenia teologii Fłorowskiego we właściwym kontekście. Mówienie o Fłorowskim jako o twórcy syntezy neopatrystycznej należałoby ograniczyć do przestrzeni rosyjskiej teologii prawosławnej. Pewne zjawiska w teologii pojawiają się równocześnie i nie można tu mówić o wpływie. Przed II wojną światową istniały we Francji dwa znaczące ośrodki studiów teologicznych: jezuicki w Lyonie-Fourvière

\footnotetext{
26 Za: tamże, s. 103.

27 Za: tamże, s. 122.

28 Por. tamże, s. 124.

29 Za: tamże, s. 127-129.

$30 \quad$ Za: tamże, s. 131.
} 
na czele z Henrim de Lubakiem i Jeanem Daniélou, i studium dominikańskie Le Saulchoir z Marie-Dominique Chenu i Yves’em Congarem. Były to szkoły niezależne od siebie, które równocześnie odkryły wartość powrotu do źródeł patrystycznych. Dla naszego tematu istotna jest obserwacja, poczyniona przez włoskiego teologa Basilia Petrà:

W rzeczywistości zainteresowanie Ojcami nie zrodziło się z nostalgii za prawosławiem i nie jest związane z odkryciem prawosławia. Trzeba raczej powiedzieć, że zainteresowanie ojcami Kościoła i odkrycie prawosławia jako znaczącego dla Zachodu rodzą się niezależnie i związane są z bardzo konkretnymi motywami historyczno-kulturalnymi ${ }^{31}$.

Szczególnie w przypadku Henriego de Lubaca trzeba podkreślić jego wolność od wpływów prawosławnych; jak pisze Petrà: „de Lubac doszedł do Ojców własnymi drogami, nie przez prawosławie, ani przez to, co działo się w kręgu paryskiej diaspory" ${ }^{32}$. Kwestia ta wydaje się oczywista i nie trzeba jej bardziej rozwijać. Została ona również pokazana w książce Teresy Obolevitch.

Chciałbym zwrócić uwagę także na inną kwestię, dotyczącą już samego zjawiska odnowy patrystycznej w prawosławnym środowisku. Jeszcze w XIX wieku istniało w Rosji kilka ośrodków, które zajmowały się myślą ojców Kościoła. Oczywiście mowa tu nie do końca o tym, co miał na myśli Fłorowski, niemniej jednak stwierdzenie, że „powrót do Ojców" zaczyna się od Fłorowskiego, byłoby krzywdzące względem ogromnej pracy dokonanej w teologicznych akademiach Rosji w XIX stuleciu. Po lekturze książki Teresy Obolevitch pozostaje wrażenie, że Fłorowski, Łosski, Kiprian Kern i Wasili Kriwoszein byli pionierami patrologii na gruncie teologii prawosławnej. Nie do końca mogę zgodzić się z takim poglądem. Jest oczywiste, że teologia prawosławna walczyła

31 B. Petrà, La teologia cattolica e la scoperta dell'Ortodossia nel secolo XX: dal „contatto rinfrescante” alla „santa alleanza”, „Vivens Homo” 19/1 (2008), s. 144.

32 Tamże, s. 149. 
o swą tożsamość, i że nie udało się jej uniknąć „niewoli babilońskiej”. Boris Bobrinskoj pisze:

Teologia prawosławna była nieustannie rozdzierana między zależnościami od kategorii zachodniej scholastyki z jednej strony, a scjentyzmem bądź pietyzmem protestantów z drugiej, co prowadziło do mechanicznego używania i wyjaławiania zbiorów lub florilegiów patrystycznych, wykorzystywanych jako oręż w polemice antyłacińskiej lub antyprotestanckiej ${ }^{33}$.

Zgadzam się z obserwacją Bobrisnkoja, która idzie w kierunku krytyki teologii prawosławnej dokonanej przez Fłorowskiego. Jednak czy nie taki los spotyka każdą żywą myśl, która nie zamyka się jedynie we własnej tradycji? Jeśli myśl jest żywa, zawsze będzie pozostawała w dialogicznym napięciu z innymi tradycjami myślenia. Bobrinskoj zwraca uwagę jeszcze na jeden niezmiernie ważny fakt.

O prawdziwej odnowie patrystycznej możemy więc mówić dopiero w Prawosławiu pobizantyjskim. Znalazła ona swój początek w tradycji hezychastycznej, która przechodziła różne niewole, jak rozżarzony węgiel pod popiołem, by się wreszcie objawić w ruchu filokalicznym XVIII wieku ${ }^{34}$.

Możemy więc mówić o „renesansie patrystycznym”, który zapoczątkowało tłumaczenie Filokalii przez Pasijusza Wieliczkowskiego i o „renesansie neopatrystycznym” zapoczątkowanym przez Fłorowskiego. Jestem przekonany, że patrystyka rosyjska posiadała niemałe osiągnięcia już pod koniec XIX wieku. Rosyjskie Akademie Teologiczne podjęły ogromny wysiłek tłumaczenia dzieł ojców Kościoła wschodniego i zachodniego. „O. Clement miał prawdopodobnie rację - pisze Bobrinskoj - stwierdzając, że «pod koniec XIX w. Rosja dysponowała, w swoim języku,

33 B. Bobrinskoj, Aktualna odnowa patrystyki w Kościele Prawosławnym, tłum. Z. Wójtowicz, „Vox Patrum” 24-29 (1993-1995), s. 17-18.

34 Tamże, s. 18. 
najwspanialszą patrystyczną biblioteką Europy»"35. Nawet jeśli te słowa są pochwałą na wyrost, to nie ulega wątpliwości, że odnowa patrystyczna zaczyna się trochę wcześniej niż programowe wystąpienia młodego Fłorowskiego. W porównaniu z pracami Wasilia Bołotowa, Niesmiełowa, Michaiła Posnowa, książki Fłorowskiego na temat ojców Kościoła wydają się po prostu skromne. Rewolucja zatrzymała ten ogromny rozkwit patrystyki, a kiedy zaczęła się ona odnawiać na Zachodzie, odnosi się wrażenie, że zaczyna ona od początku. Jestem przekonany, że na krytyczną monografię zasługuje akademicka teologia drugiej połowy XIX wieku opracowana nie tylko pod kątem relacji wiary i rozumu, ale również ze względu na jej wkład w odnowę patrystyczną. Fakt przesunięcia granicy czasowej renesansu patrystycznego wydaje się bardzo ważny ze względu na zachowanie ciągłości myśli teologicznej.

Pozostaje jeszcze trzecia kwestia związana ze zjawiskiem renesansu patrystycznego. Wydaje się konieczne przesunięcie granic renesansu patrystycznego nie tylko w czasie, ale i przestrzeni. Teza Fłorowskiego o hellenizacji chrześcijaństwa ogranicza zasięg patrystyki do Kościołów tradycji bizantyjskiej. Ogromną wagę innych źródeł patrystycznych dostrzegano już dawno. Chciałbym przytoczyć fragment wykładu wygłoszonego na Uniwersytecie Warszawskim w 1933 roku przez o. Grzegorza Peradze.

Szczególne zadanie ma patrologia jako wiedza na Wydziale Teologii Prawosławnej. Wynika to ze specjalnego stanowiska, jakie Kościół prawosławny zajmuje między Kościołem rzymskokatolickim i protestanckim, a po drugie ze szczególnego i nader silnego zainteresowania, jakie w Europie zdobyła patrologia, mająca tak istotne znaczenie dla Kościoła prawosławnego. [...] Do narodów prawosławnych zaliczają się Słowianie, o ile nie są katolikami, Grecy, Gruzini, Rumuni, Arabowie... [...] Do heretyckich zaś Kościołów - monofizyckiego, nestoriańskiego i jakobickiego - należy większa część Ormian, Syryjczyków, Koptów i wszyscy Etiopczycy. Patrologia zajmuje się bardzo pilnie i dokładnie literaturą tych narodów. [...] W rzeczywistości zaś teologia

35 Tamże. Bobrinskoj odsyła do przewodnika bibliograficznego opracowanego przez o. Kipriana Kerna i opublikowaną przez Editions de Chevetogne w 1957 roku pt. Les traductions russes des textes patristiques. 
prawosławna oprócz kilku prac i wspaniałych kolekcji nie zrobiła nic systematycznego w tym kierunku, zaś przewodnikami i mistrzami są inni. [...] Na Wydziale Teologii Prawosławnej Uniwersytetu Warszawskiego obok patrologii greckiej i łacińskiej powinna znaleźć miejsce także inna literatura wschodniochrześcijańska ${ }^{36}$.

Wypowiedź ta pochodzi jeszcze sprzed programowego wystąpienia Fłorowskiego. Prawosławny renesans patrystyczny wymaga dostrzeżenia źródeł innych niż bizantyjskie. „Neopatrystyczna synteza” zaproponowana przez Fłorowskiego była niejednokrotnie krytykowana ze strony samych prawosławnych teologów. W opracowaniu Teresy Obolevitch zabrakło niestety zdania relacji z krytycznej dyskusji wokół postulatów renesansu patrystycznego ${ }^{37}$. Byłoby to bardzo ciekawe uzupełnienie dyskusji współczesnych teologów.

W moim przekonaniu twórcza kontynuacja programu Fłorowskiego możliwa jest przy uwzględnieniu przynajmniej trzech wyżej wspomnianych kontekstów patrystycznych. Przede wszystkim jednak wydaje się konieczne odnalezienie ciągłości i dialogu pomiędzy różnymi nurtami teologii prawosławnej XIX i XX stulecia. Książka Teresy Obolevitch jest znaczącym wkładem w formowanie tego dialogu. Mam nadzieję, że za jej publikacją pojawią się następne, które w tak rzetelny sposób będą nam przybliżały historię i kreśliły drogi rozwoju rosyjskiej filozofii i teologii.

36 G. Peradze, Pojęcie, zadania i metody patrologii w teologii prawosławnej, „Vox Patrum” 16 (1996), s. 344-346.

37 Odsyłam do artykuł greckiego teologa Pantelisa Kalaitzidisa, znakomicie wprowadzającego w problematykę: П. Калаицидис, От «возвращения к отияам» к необходимости современного православного богословия, tłum. А. Авдохина, http://www.bogoslov.ru/text/ print/2586215.html. 